Article

\title{
Effect of Al Content in Magnesium Alloy on Microstructure and Mechanical Properties of Laser-Welded Mg/Ti Dissimilar Joints
}

\author{
Wen Dong ${ }^{1}$, Rongrong Huang ${ }^{2,3}$, Hongyun Zhao ${ }^{2,3}$, Xiangtao Gong ${ }^{4}$, Bo Chen ${ }^{3}$ \\ and Caiwang Tan $2,3, *$ \\ 1 Changchun Institute of Technology, Changchun 130000, China; 19b909121@stu.hit.edu.cn \\ 2 State Key Laboratory of Advanced Welding and Joining, Harbin Institute of Technology, \\ Harbin 150001, China; 19s130339@stu.hit.edu.cn (R.H.); zhaohy6691@hit.edu.cn (H.Z.) \\ 3 Shandong Provincial Key Laboratory of Special Welding Technology, \\ Harbin Institute of Technology at Weihai, Weihai 264209, China; chenb@hit.edu.cn \\ 4 Department of Mechanical and Aerospace Engineering, Missouri University of Science and Technology, \\ Rolla, MO 65401, USA; xgxfv@umsystem.edu \\ * Correspondence: tancaiwang@hitwh.edu.cn
}

Received: 12 May 2020; Accepted: 11 June 2020; Published: 17 June 2020

\begin{abstract}
Laser penetration welding of magnesium alloys and pure titanium TA2 with unequal thickness was performed. Mg base metal with different Al content (AZ31B, AZ61A, AZ91D) was used to investigate the influence of $\mathrm{Al}$ element in microstructure and mechanical properties of $\mathrm{Mg} / \mathrm{Ti}$ dissimilar joints. The results revealed that the change of $\mathrm{Mg}$ base metal did not influence the weld appearance of the joints. Three kinds of joint all presented the best mechanical property when the laser power was $3500 \mathrm{~W}$. With the increase content of $\mathrm{Al}$ elements in $\mathrm{Mg}$ base metal, a reaction layer was observed which was identified as $\mathrm{Ti}_{3} \mathrm{Al}$. The highest enrichment of $\mathrm{Al}$ element was obtained and its fraction reached 19.31 at $\%$ at the AZ91/TA2 interface. The chemical potential gradient of Al from AZ91 to Ti alloy was higher than that from the other two base metals based on thermodynamic calculation. The maximum fracture load reached $3597 \mathrm{~N}$ when AZ61 was employed as the base metal and the fracture position was the Ti base metal. AZ31/TA2 joints failed at the weld seam without necking due to the rapid propagation of cracks at the $\mathrm{Mg} / \mathrm{Ti}$ interface. The AZ91/TA2 joint failed inside the $\mathrm{Mg}$ fusion zone with necking at the middle area of the weld, which resulted from the precipitation of brittle phases such as $\mathrm{Mg}-\mathrm{Al}, \mathrm{Ti}-\mathrm{Al}$ phases in the fusion zone of $\mathrm{Mg}$ alloys.
\end{abstract}

Keywords: $\mathrm{Mg} / \mathrm{Ti}$ dissimilar joints; laser welding; microstructure; interface reaction; mechanical properties

\section{Introduction}

Nowadays, hybrid components of lightweight materials have been receiving extensive attention to achieve reduction of emissions and green development, which increases the demand for weight reduction in advanced manufacturing industry [1-4]. Magnesium (Mg), as one of the lightest engineering structural materials, has attracted wide attention due to its advantages of high strength, excellent formability and recyclability [5-7]. Titanium (Ti) has many features, such as high strength-to-weight ratio, good impact toughness and corrosion resistance [8,9]. The application of $\mathrm{Mg} / \mathrm{Ti}$ dissimilar metal in spacecraft, such as the tail cabin and engine bracket, is of particular interest since the hybrid component would further reduce overall weight. Therefore, it is urgent to achieve reliable joining of $\mathrm{Mg} / \mathrm{Ti}$ dissimilar metals $[10,11]$. 
However, achieving reliable bonding between $\mathrm{Mg} / \mathrm{Ti}$ alloys needs to overcome the huge differences in theirs physical, chemical and metallurgical properties. No reaction layer or little solid solubility occurs, due to their immiscibility characteristics. The huge differences between the melting point of $\mathrm{Mg}$ $\left(649^{\circ} \mathrm{C}\right)$ and $\mathrm{Ti}\left(1678^{\circ} \mathrm{C}\right)$ lead to severe burning and evaporation of the $\mathrm{Mg}$ alloy if using a traditional welding process. Besides, residual stress and deformation easily appear in the $\mathrm{Mg} / \mathrm{Ti}$ dissimilar joints. In response to the above problems, investigations have been carried out and the results suggested that metallurgical reaction could be achieved by adding alloying elements such as $\mathrm{Al}, \mathrm{Cu}, \mathrm{Ni}$ [12-15] which can react with or possess obvious solid solubility in $\mathrm{Mg}$ and Ti alloy.

As for the influence of $\mathrm{Al}$ element on $\mathrm{Mg} / \mathrm{Ti}$ welding, Cao et al. [16] carried out welding-brazing of TA2 and AZ31B using cold metal transfer (CMT) technique and found that the diffusion behavior of $\mathrm{Al}$ element in $\mathrm{Mg}$ alloy base metal and filler metal at the interface was an important factor contributing to the reliable joining of the $\mathrm{Mg} / \mathrm{Ti}$ joint. Hu et al. [17] performed $\mathrm{Mg} / \mathrm{Ti}$ laser welding-brazing with pure $\mathrm{Al}$ wire and found that a compound layer with the thickness of $1-2 \mu \mathrm{m}$ was formed at the $\mathrm{Mg} / \mathrm{Ti}$ interface. Energy-dispersive X-ray spectrometry (EDS) results showed that the main elements consisted of $\mathrm{Mg}, \mathrm{Al}$ and $\mathrm{Zn}$. Tan et al. [18] investigated the diffusion behavior of $\mathrm{Mg}-\mathrm{Al}-\mathrm{Ti}$ ternary system by thermodynamic calculation. It was revealed that $\mathrm{Al}$ element has a lower chemical potential on the $\mathrm{Ti}$ side, which promoted the uphill diffusion from the $\mathrm{Mg}$ alloy base metal to titanium alloy at the interface. $\mathrm{Al}-\mathrm{Ti}$ intermetallic compound had a higher driving force of precipitation during the reaction process. It was concluded from the above results that Al element could not only have a large proportion of mutual solubility with $\mathrm{Mg}$ alloy, but also interact with Ti alloys to generate interfacial reaction layer, which played an important role in regulating $\mathrm{Mg} / \mathrm{Ti}$ dissimilar welding. Moreover, the addition method and content of Al element also affect the weldability of $\mathrm{Mg} / \mathrm{Ti}$ joints. When the $\mathrm{Al}$ element was fed into the molten pool through filler metal, the joint strength using AZ91 filler was greatly improved compared with AZ31 filler wire under various experimental parameters [18,19]. Zang et al. [20] the Al content accurately by changing the thickness of the $\mathrm{Al}$ interlayer. They found that the thickness of TiAl3 did not change obviously with the increasing $\mathrm{Al}$ interlayer thickness. However, the intermetallic compound became denser in the $\mathrm{Mg}$ fusion zone which damaged the mechanical property of $\mathrm{Mg} / \mathrm{Ti}$ joints. The effect of $\mathrm{Al}$ on welding of $\mathrm{Mg}$ to Ti was also noticed in the friction stir welding (FSW) process. Aonuma et al. [21] performed FSW welding of pure titanium to different Mg sheets (AZ31B, AZ61A and AZ91D) to explore the effect of $\mathrm{Al}$ content on the interfacial microstructure of $\mathrm{Mg} / \mathrm{Ti}$ joints. The diffusion of $\mathrm{Al}$ element was found to be different due to different content in $\mathrm{Mg}$ base metal. The thickness of the Ti-Al compound layer increased and the mechanical property declined with the increase of $\mathrm{Al}$ content.

At present, welding-brazing method was widely employed on $\mathrm{Mg} / \mathrm{Ti}$ dissimilar metals while researches on deep penetration welding of thick plates were rarely reported. To the best of our knowledge, there are no investigations about influence of $\mathrm{Al}$ element as alloying element from $\mathrm{Mg}$ base metal on interfacial reaction and mechanical properties of laser welded $\mathrm{Mg} / \mathrm{Ti}$ joints. In this study, laser deep penetration welding of $\mathrm{Mg} / \mathrm{Ti}$ with unequal thickness was performed. Different $\mathrm{Mg}$ base metals (AZ31B, AZ61A, AZ91D) were used to join TA2. The purpose of this work was to establish the relationship between $\mathrm{Al}$ content and interfacial microstructure and thermodynamics, which lay a good foundation for the selection of the suitable base metal in the actual applications of $\mathrm{Mg} / \mathrm{Ti}$ laser penetration welding with unequal thickness.

\section{Materials and Methods}

In this work, three types of magnesium alloys with different Al contents (AZ31B, AZ61A, AZ91D) were selected as base metals in dimension of $100 \mathrm{~mm} \times 50 \mathrm{~mm} \times 3 \mathrm{~mm}$. The base metal of titanium was TA2 with the dimensions of $100 \mathrm{~mm} \times 50 \mathrm{~mm} \times 1 \mathrm{~mm}$. The chemical composition of the base metal was shown in Table 1. A $6 \mathrm{~kW}$ fiber laser (IPG-6000) (IPG Photonics Corporation, Oxford, MA, USA) with $1070 \mathrm{~nm}$ wavelength and KUKA KR60HA (KUKA, Augsburg, Germany) six-axis robot were used for welding. A Precitec YW52 (Precitec, Baden-Baden, Germany) welding head was employed with a linear design and a focal length of $300 \mathrm{~mm}$. The focused spot size was $0.4 \mathrm{~mm}$. Figure 1 shows the 
schematic of laser welding of $\mathrm{Mg} / \mathrm{Ti}$ with unequal thickness. The assembly was adopted in a butt configuration with the gap of $0 \mathrm{~mm}$. In order to ensure the full melting of the thick magnesium alloy, laser beam was irradiated on the surface of the $\mathrm{Mg}$ vertically and the laser offset distance to $\mathrm{Mg}$ was $0.3 \mathrm{~mm}$. The defocused distance was selected as $-1.5 \mathrm{~mm}$ with the beam spot dimension of $0.67 \mathrm{~mm}$ in order to avoid a large amount of burning of the $\mathrm{Mg}$ base metal. Ar gas was blown behind the laser beam as the shielding gas and under the weld seam to conduct root protection with the flow rate of $15 \mathrm{~L} / \mathrm{min}$ to protect molten pool from oxidation. After several preliminary trials, the laser power adopted was in the range of 2.5-5.0 $\mathrm{kW}$ matching the welding speed of $1.5 \mathrm{~m} / \mathrm{min}$. The welding parameters employed in this work were shown in Table 2. The joints with the best performance were selected for further detailed analysis through comparing the weld appearances and mechanical property of the samples with different laser powers. During the welding process, $1 \mathrm{~mm}$-thick shim was adopted on the thin Ti side to ensure that the thickness of the base metal was centered. The experiments performed with each laser power and $\mathrm{Mg}$ base metal were repeated three times.

Table 1. Chemical compositions of base metals (wt.\%).

\begin{tabular}{cccccccc}
\hline Materials & Al & Zn & Mn & Fe & Si & Mg & Ti \\
\hline AZ31B & 3.00 & 0.88 & 0.58 & 0.018 & 0.015 & Bal. & - \\
AZ61A & 6.40 & 0.70 & 0.24 & 0.003 & 0.030 & Bal. & - \\
AZ91D & 9.17 & 0.65 & 0.28 & 0.002 & 0.020 & Bal. & - \\
TA2 & - & - & - & 0.070 & - & - & Bal. \\
\hline
\end{tabular}

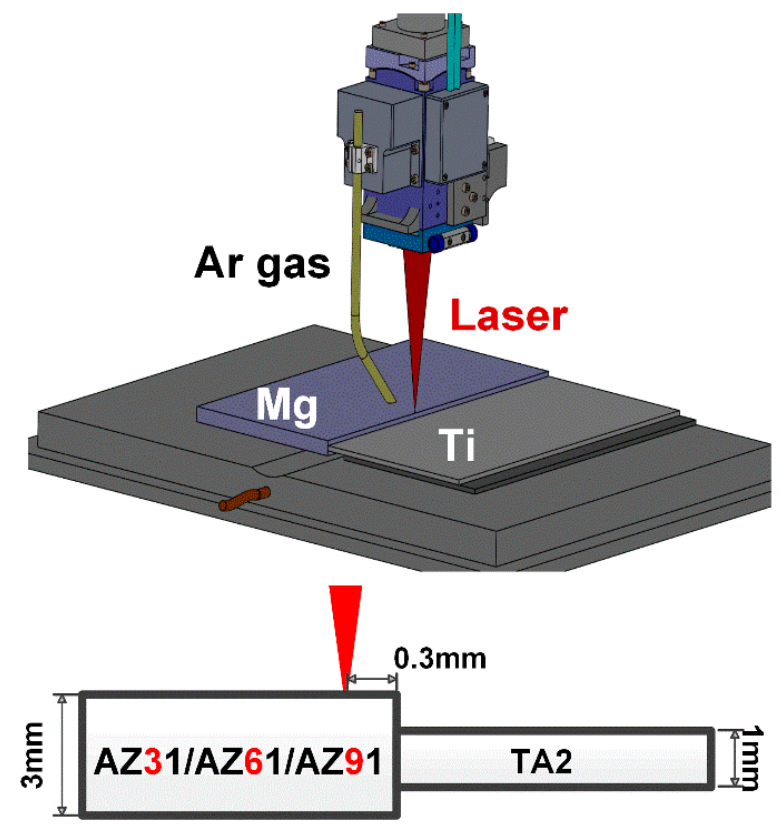

Figure 1. Schematic of laser deep penetration welding of $\mathrm{Mg} / \mathrm{Ti}$ dissimilar joints.

Table 2. Welding parameters used in present work.

\begin{tabular}{cc}
\hline Experimental Parameters & Value \\
\hline Mg base metal & AZ31B/AZ61A/AZ91D \\
Laser power, $\mathrm{W}$ & $2500,3000,3500,4000,4500,5000$ \\
Defocused distance, $\mathrm{mm}$ & -1.5 \\
Welding speed, $\mathrm{m} / \mathrm{min}$ & 1.5 \\
Shielding gas flow rate, $\mathrm{L} / \mathrm{min}$ & 15 \\
Laser offset to $\mathrm{Mg}$ side, $\mathrm{mm}$ & 0.3 \\
\hline
\end{tabular}


$\mathrm{Mg}$ and Ti were easy to oxidize in the air due to active chemical properties. Before the experiment, mechanical and chemical cleaning were undertaken to remove the surface oxide film. Ti sheets was cleaned in the acid solution with the composition of $5 \% \mathrm{HF}+15 \% \mathrm{HCl}+80 \%$ distilled water and magnesium alloy was polished with a grinder and sandpaper. After the laser-welding process, typical areas of specimens with the dimension of $20 \mathrm{~mm} \times 10 \mathrm{~mm}$ were cut to observe the cross section morphology of the joints. The samples were etched in acid solution $(5.5 \mathrm{~g}$ picric acid, $2 \mathrm{~mL}$ acetic acid, $90 \mathrm{~mL}$ absolute alcohol and $10 \mathrm{ml}$ distilled water) for $15 \mathrm{~s}$ to obtain the fusion line on the $\mathrm{Mg}$ side. The morphology of the sample was observed with an ultra-depth optical microscope (OLMPUS-DSX510) (OLMPUS Corporation, Beijing, China) and scanning electron microscope (SEM) with EDS (Carl Zeiss AG, Jena, Germany). The welded samples were cut perpendicular to the weld direction with a dimension of $10 \mathrm{~mm} \times 80 \mathrm{~mm}$ for the tensile test. An electronic tensile tester (INSTRON MODEL 5967) (INSTRON CORPORATION, Shanghai, China) was used for the tensile test with a speed of $1 \mathrm{~mm} / \mathrm{min}$ at room temperature according to the GB/T 2651-2008 standard [22]. In this study, the maximum load was used to express the tensile property of the overall joint due to the different cross-sectional areas of fracture. Three tensile samples from the same welded plates were prepared for tensile testing. The average value of the maximum tensile load was taken and the error range was calculated. The fracture surface was observed and analyzed by SEM.

In order to analyze the driving force of the diffusion behaviors of atoms, thermodynamic calculations were performed. In the theory of thermodynamics, the driving force of elemental diffusion is the chemical potential. The Miedema model and Toop model were adopted to analyze the diffusion and aggregation of $\mathrm{Al}$ and $\mathrm{Ti}$.

The Gibbs free energy of Mg-Al-Ti ternary system was calculated through the Toop model [23] which was an extended asymmetry model developed from Miedema model [24]. The Gibbs free energy and the chemical potential of elements were calculated through the following equations:

$$
\begin{gathered}
G^{E}=\frac{x_{2}}{1-x_{1}} G_{12}^{E}\left(x_{1}, 1-x_{1}\right)+\frac{x_{3}}{1-x_{1}} G_{13}^{E}\left(x_{1}, 1-x_{1}\right)+\left(x_{2}+x_{3}\right)^{2} G_{23}^{E}\left(\frac{x_{2}}{x_{2}+x_{3}}, \frac{x_{3}}{x_{2}+x_{3}}\right) \\
G_{m}=G^{I D}+G^{E} \\
\mu_{i}=\frac{\partial G_{m}}{\partial x_{i}}
\end{gathered}
$$

where $G^{E}$ and $G_{i j}^{E}$ represented the molar excess Gibbs energies. $G_{m}$ and $G^{I D}$ were Gibbs free energy and ideal solution approximation, respectively. $\mu_{i}$ represented chemical potential of element $\mathrm{i}$ and $x_{i}$ was the mole fraction of $i$.

In the binary system, $G_{i j}^{E}$ could be calculated through $\Delta H_{1,2}$ and the relationship between them is shown as follows:

$$
G_{12}^{E}=\Delta H_{1,2}\left[1-\left(\frac{1}{T_{m, 1}}+\frac{1}{T_{m, 2}}\right) / 14\right]
$$

where $\Delta H$ was the formation enthalpy of binary system. $T_{m}$ was the melting point of components.

$\Delta H$ in the binary system could be calculated applying to the Miedema model.

$$
\begin{gathered}
\Delta H_{1,2}=f_{1,2} \frac{x_{1}\left[1+\mu_{1} x_{2}\left(\varphi_{1}-\varphi_{2}\right)\right] x_{2}\left[1+\mu_{2} x_{1}\left(\varphi_{2}-\varphi_{1}\right)\right]}{x_{1} V_{1}^{\frac{2}{3}}\left[1+\mu_{1} x_{2}\left(\varphi_{1}-\varphi_{2}\right)\right]+x_{2} V_{2}^{\frac{2}{3}}\left[1+\mu_{2} x_{1}\left(\varphi_{2}-\varphi_{1}\right)\right]} \\
f_{1,2}=\frac{2 p V_{1}^{\frac{2}{3}} V_{2}^{\frac{2}{3}}\left[q / p\left(\Delta n_{W S}^{1 / 3}\right)^{2}-(\Delta \varphi)^{2}-\alpha(r / p)\right]}{\left(\Delta n_{W S}^{1 / 3}\right)_{1}^{-1}+\left(\Delta n_{W S}^{1 / 3}\right)_{2}^{-1}}
\end{gathered}
$$

where $\varphi$ represented the electronegativity, $V$ was the molar volume, $n_{w s}$ was the electron density, and $q$, $r, \mu, a, p$ were experimental constants. Physical parameters and values listed in Table 3. 
Table 3. Parameters adopted for Mg, Al and Ti elements in Formulas (4)-(6).

\begin{tabular}{ccccccc}
\hline Elements & $\boldsymbol{T}_{\boldsymbol{m}} / \mathbf{K}$ & $\boldsymbol{n}_{\text {ws }} / \mathbf{d . u}$. & $\boldsymbol{\varphi} / \mathbf{V}$ & $\boldsymbol{u}$ & $\boldsymbol{V} / \mathbf{c m}^{\mathbf{3}}$ & $\boldsymbol{R} / \mathbf{P}$ \\
\hline $\mathrm{Mg}$ & 922 & 1.6 & 3.45 & 0.1 & 14 & 0.4 \\
$\mathrm{Al}$ & 933.6 & 2.7 & 4.2 & 0.07 & 10 & 1.9 \\
$\mathrm{Ti}$ & 1933 & 3.51 & 3.8 & 0.04 & 10.58 & 1 \\
\hline
\end{tabular}

\section{Results and Discussion}

\subsection{Joint Appearances and Cross Sections}

Magnesium alloys were easy to evaporate and burn during the welding process due to their lower melting point $\left(649^{\circ} \mathrm{C}\right)$ and boiling point $\left(1107^{\circ} \mathrm{C}\right)$. In order to obtain high-quality $\mathrm{Mg} / \mathrm{Ti}$ laser-welded joints, experiments were first conducted with different heat inputs to explore the optimal welding parameters. The stability of the welding process and the weld appearances without obvious defects were carried as the reference to evaluate the suitability of the welding parameters. It was found that the joint appearance of the welded seam did not change obviously when different $\mathrm{Mg}$ base metal was used under the same welding parameters. To avoid repetition, only one set of results was presented. Figure 2 showed representative appearances of AZ61/TA2 laser welded joints with unequal thickness produced at different laser powers. As shown in Figure $2 \mathrm{a}, \mathrm{b}$, the weld width was small due to the lower heat input employing laser power of $2.5 \mathrm{~kW}$ and $3.0 \mathrm{~kW}$. Figure $2 \mathrm{c}-\mathrm{e}$ indicated that the weld width increased with the increase of laser power. Besides, the increasing effect on the front side of the weld was small while the significant effect on the back side appeared. It was mainly attributed to the formation of the keyhole during the welding process due to the higher laser energy density acting on the weld. As the laser power increased, the penetration of the keyhole increased resulting in the rapid collapse of the front side of the molten metal and the increased fluidity of the molten metal on the back side. The back surface of the weld was rough because of the instability of the molten pool under the effect of gravity. When the laser power increased to $5 \mathrm{~kW}$, molten metal collapsed seriously and over-burning defect was obtained as shown in Figure 2f. The molten pool spread poorly on the back surface of the joints.

Figure 3 showed cross-sectional morphology of $\mathrm{Mg} / \mathrm{Ti}$ joints under different laser powers. During the welding process, both $\mathrm{Mg}$ alloy and TA2 were partially melted. The red line in Figure 3 was the fusion line. The entire joints could be divided into two parts: fusion zone of $\mathrm{Mg}$ and fusion zone of Ti. Due to the low melting point of $\mathrm{Mg}$ and the laser offset to the $\mathrm{Mg}$ side, the melting area of the $\mathrm{Mg}$ alloy was larger than that of Ti. The seam width and spread width at the corresponding position in Figure 3 were measured and the results are shown in Figure 4. Among them, the seam width was defined as the distance from the fusion line at $\mathrm{Mg}$ side to the left side of the Ti fusion zone and the spread width was defined as the distance from the right side of $\mathrm{Mg}$ alloys to the left side of the $\mathrm{Ti}$ fusion zone at the upper and lower surface. The schematic diagrams of the measurement location are shown in Figure 4. With the increase of laser power, the upper surface of welding seam gradually collapsed and the seam width at the upper face was larger than that at the lower surface. With the increase of laser power, the melting amount reflected from the seam width of magnesium alloy was increasing slightly on the upper surface $(0.98 \mathrm{~mm}-2.27 \mathrm{~mm})$ while significantly on the lower surface $(1.3 \mathrm{~mm}-3.16 \mathrm{~mm})$, which was consistent with the welding appearance. In addition, larger heat input improved the spread width of the melting metal on the Ti side at the lower surface $(0.29 \mathrm{~mm}-1.6 \mathrm{~mm})$ as shown in Figure $4 \mathrm{~b}$. The fusion zone on the Ti side appeared semicircular. The melting amount at the upper and lower side was significantly greater than the middle. During the welding process, two molten pool on the upper and lower sides of the Ti side existed with the keyhole as the boundary, which resulted in the heat input at the upper and lower side being greater than the middle position [25]. In summary, the quality of the weld appearance was an important factor in evaluating the welding quality of the joint. Uniform and sound appearance contributed to the improvement of joint strength. When the laser power was low, the melting amount of base metal was insufficient to achieve reliable 
joining while excessive heat input would limit the improvement of mechanical property of the joint due to the presence of the welding defects.
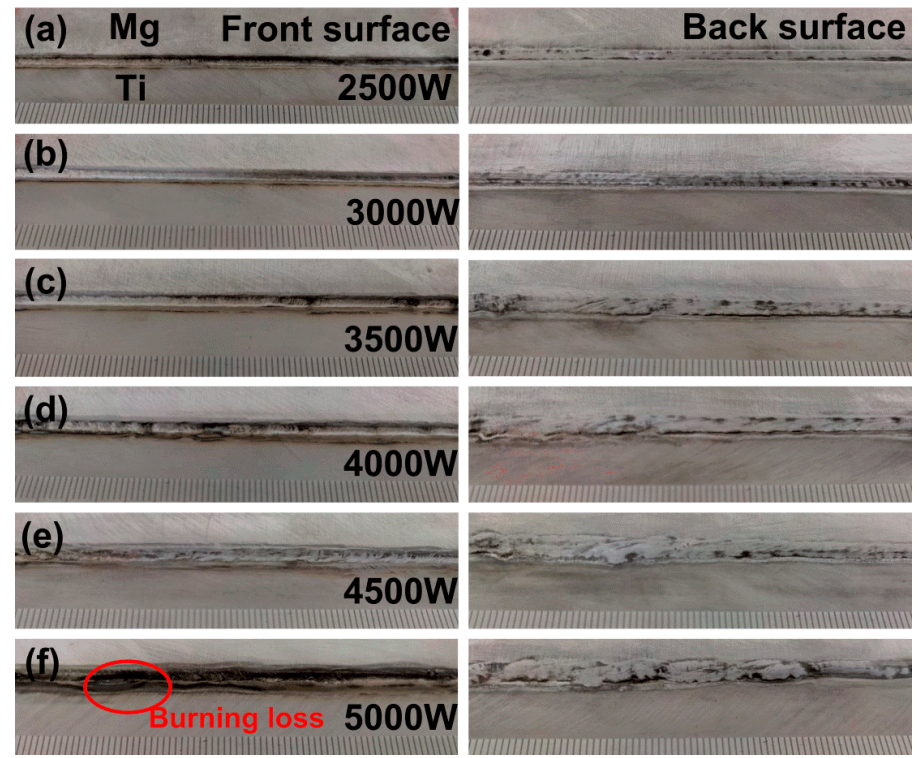

Figure 2. Full weld profile of laser deep penetration of AZ61/TA2 with variation of laser power: (a) $2.0 \mathrm{~kW}$; (b) $2.5 \mathrm{~kW}$; (c) $3.0 \mathrm{~kW}$; (d) $3.5 \mathrm{~kW}$; (e) $4.0 \mathrm{~kW}$; (f) $5.0 \mathrm{~kW}$.
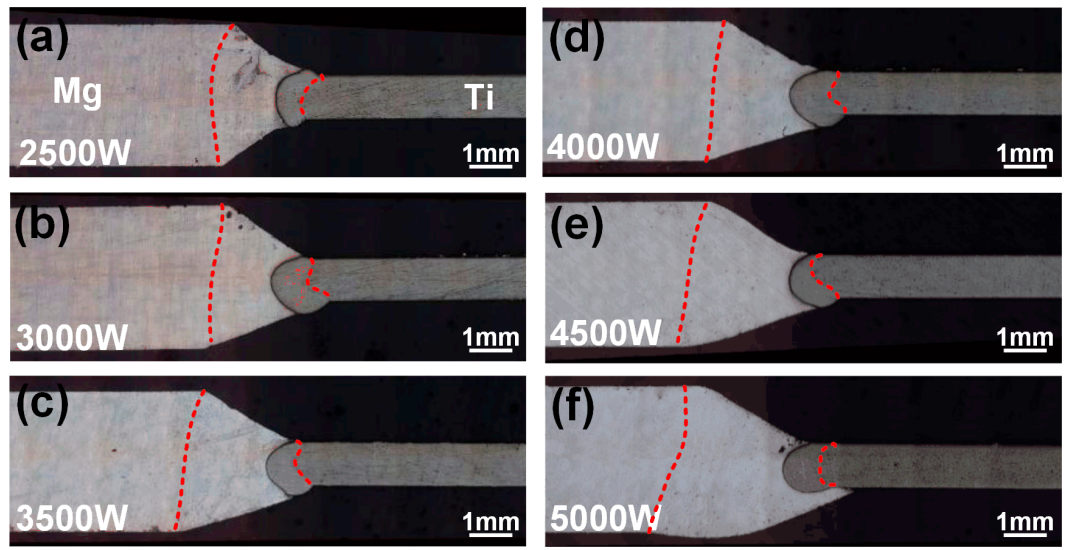

Figure 3. Cross sections morphology of laser deep penetration welding of AZ61/TA2 at various laser power: (a) $2.0 \mathrm{~kW}$; (b) $2.5 \mathrm{~kW}$; (c) $3.0 \mathrm{~kW}$; (d) $3.5 \mathrm{~kW}$; (e) $4.0 \mathrm{~kW}$; (f) $5.0 \mathrm{~kW}$.
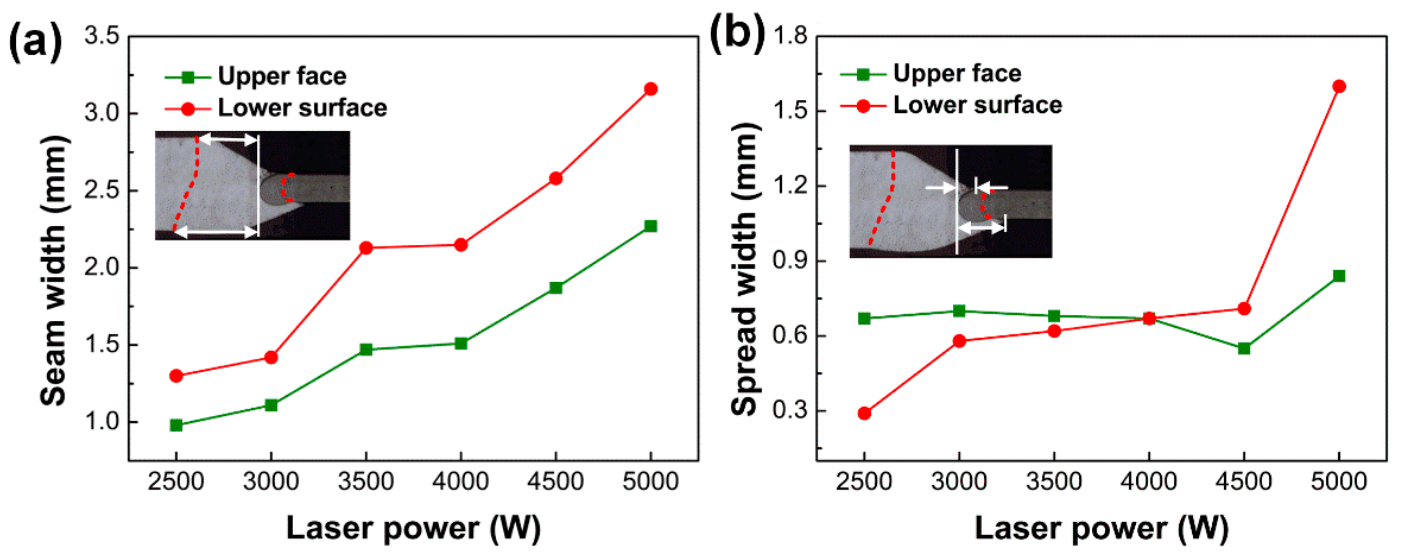

Figure 4. The position and results of measurement in Figure 3: (a) seam width; (b) spread width. 


\subsection{Mechanical Property}

Tensile test was conducted to evaluate mechanical property of the $\mathrm{Mg} / \mathrm{Ti}$ laser welded joints and the results are shown in Figure 5. The variation of joint strength produced with different Mg alloy base metal was found to present the similar trend with the increase of the laser power. Poor joint performance occurred in the case of low laser power. With the laser power increasing, the tensile load of the joints increased rapidly and reached the maximum at laser power of $3.5 \mathrm{~kW}$. The maximum load was $3597 \mathrm{~N}$ of AZ61/TA2, 3346 N of AZ91/TA2 and $3114 \mathrm{~N}$ of AZ31/TA2. With a further increase of laser power the joint strength decreased, which was related to the collapse of the weld as shown in Figure 3. In order to further explore the influence of $\mathrm{Al}$ content on the quality of $\mathrm{Mg} / \mathrm{Ti}$ deep penetration joints, joints with the highest fracture load which performed at laser power of $3.5 \mathrm{~kW}$ was selected to analyze the microstructure and fracture behaviors in the next sections.

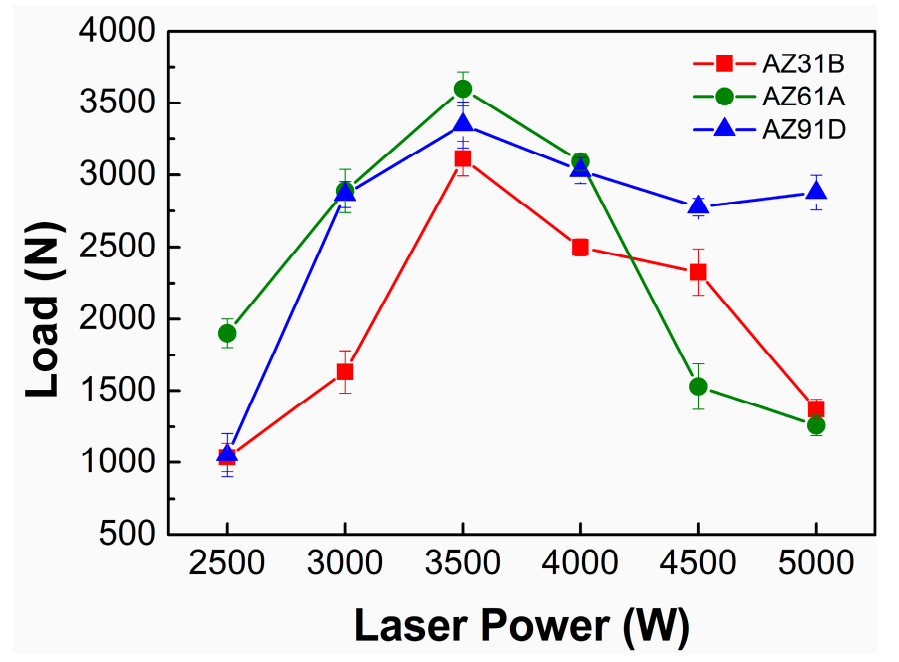

Figure 5. Fracture load of laser deep penetration welding of $\mathrm{Mg} / \mathrm{Ti}$ at various laser powers.

\subsection{Interfacial Microstructure}

Figure 6 showed the interfacial microstructure of $\mathrm{Mg} / \mathrm{Ti}$ laser welded joints with different $\mathrm{Mg}$ base metal using laser power of $3.5 \mathrm{~kW}$. The observed locations were also indicated in the images, which were the upper, middle and lower parts of the joints. Figure 6a-c shows the interfacial morphology of the AZ31/TA2 joints, and no obvious interfacial reaction layer was observed in the upper and middle parts of the joints while a thin interfacial reaction layer appeared in the lower part. Compared with the AZ31/TA2 joint, an ultra-thin reaction layer grew from the surface of the Ti in the middle of the joints when the AZ61 base metal was employed as shown in Figure 6e. The feature was observed to display discontinuous and serrate-shaped morphology. When the $\mathrm{Al}$ content of the $\mathrm{Mg}$ alloy base metal continued to increase, a clear interface reaction layer could be seen in the middle and lower parts of the $\mathrm{Mg} / \mathrm{Ti}$ interface. Compared with the other two joints, the thickness of the reaction layer in the middle parts of the AZ91/TA2 joints increased significantly. The formation of a reaction layer indicated that metallurgical bonding was achieved at $\mathrm{Mg} / \mathrm{Ti}$ interface. The possibility of improved bonding between $\mathrm{Mg}$ and $\mathrm{Ti}$ by adding more $\mathrm{Al}$ content into $\mathrm{Mg}$ alloy base metal was confirmed. The reaction interfacial layer was mainly identified as the $\mathrm{Ti}_{3} \mathrm{Al}$ via transmission electron microscopy (TEM) (JEOL, Tokyo, Japan) analysis, which was reported in our previous study [19]. The EDS results at the interfacial reaction layer (P3) in this study (as shown in Table 4) also confirmed this finding. In addition, the precipitation of scattered white phase as $\mathrm{Mg}_{17} \mathrm{Al}_{12}$ was obviously observed at the fusion zone at Mg side for AZ61/TA2 and AZ91/TA2 joints. Zang et al. also obtained similar results [19]. 


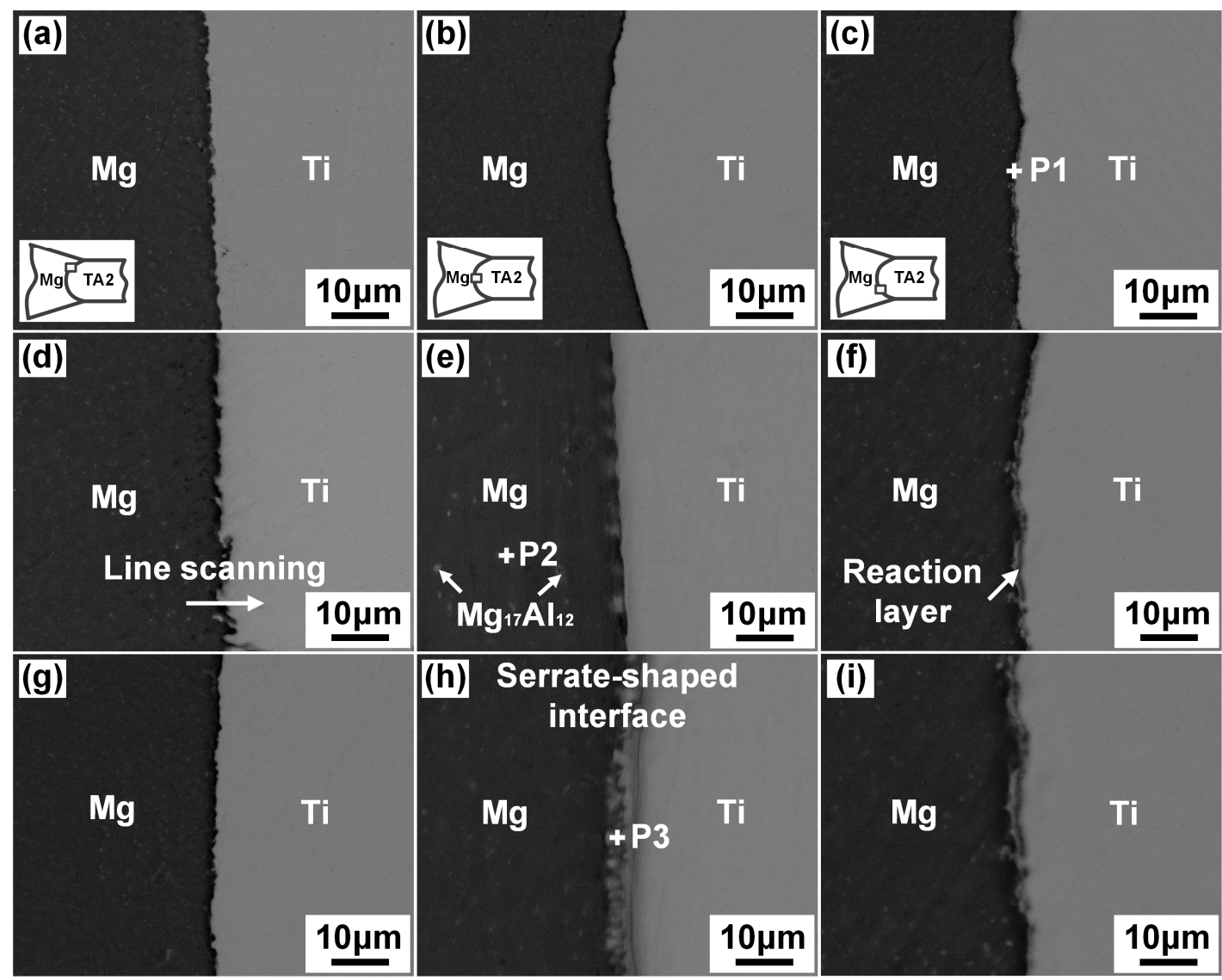

Figure 6. Interfacial microstructure of laser deep penetration welding of $\mathrm{Mg} / \mathrm{Ti}$ at $3.5 \mathrm{~kW}$ : (a-c) AZ31/TA2; (d-f) AZ61/TA2; (g-i) AZ91/TA2.

Table 4. Energy-dispersive X-ray spectrometry (EDS) analysis results of points in Figure 6 (at\%).

\begin{tabular}{ccccc}
\hline Point & Mg & Al & Ti & Possible Phases \\
\hline 1 & 89.21 & 6.11 & 4.68 & $\mathrm{Mg}$ \\
2 & 68.27 & 31.44 & 0.29 & $\mathrm{Mg}_{17} \mathrm{Al}_{12}$ \\
3 & 12.76 & 27.08 & 60.16 & $\mathrm{Ti}_{3} \mathrm{Al}$ \\
\hline
\end{tabular}

The reaction layer at the $\mathrm{Mg} / \mathrm{Ti}$ interface was thin and the morphology were blurred since small $\mathrm{Al}$ content in the $\mathrm{Mg}$ base metal was involved into the interfacial reaction [25]. Therefore, line scanning analysis across the $\mathrm{Mg} / \mathrm{Ti}$ interface was performed through SEM-EDS testing to obtain the concentration profiles of the main elements in order to estimate the degree of interface reaction and the results are shown in Figure 7. On the whole, the $\mathrm{Mg}$ content of decreased while the Ti content increased at the interface. Al element segregation was observed at the interface of $\mathrm{Mg} / \mathrm{Ti}$ indicating the appearance of atomic diffusion of $\mathrm{Al}$ from the $\mathrm{Mg}$ base metal to $\mathrm{Mg} / \mathrm{Ti}$ interface. However, the enrichment degree of $\mathrm{Al}$ was different using different $\mathrm{Mg}$ alloy base metal. The enrichment of Al element was not obvious in the upper and middle regions for the AZ31/TA2 joints. While at the bottom of the joint, the atomic fraction of $\mathrm{Al}$ element at the interface reached $12.96 \mathrm{at} \%$. When using AZ61 as the base metal, Al element was obviously enriched in the middle and lower parts of the joint and the highest $\mathrm{Al}$ content at the lower parts could reach 15.62 at $\%$. With the Al content continually increased to $9 \mathrm{wt} \%$, Al significantly enriched at the whole regions along the interface compared with the other two joints and the highest $\mathrm{Al}$ content increased to $19.31 \mathrm{at} \%$ which indicated the great reaction during the metallurgical bonding of $\mathrm{Mg}$ and $\mathrm{Ti}$. 

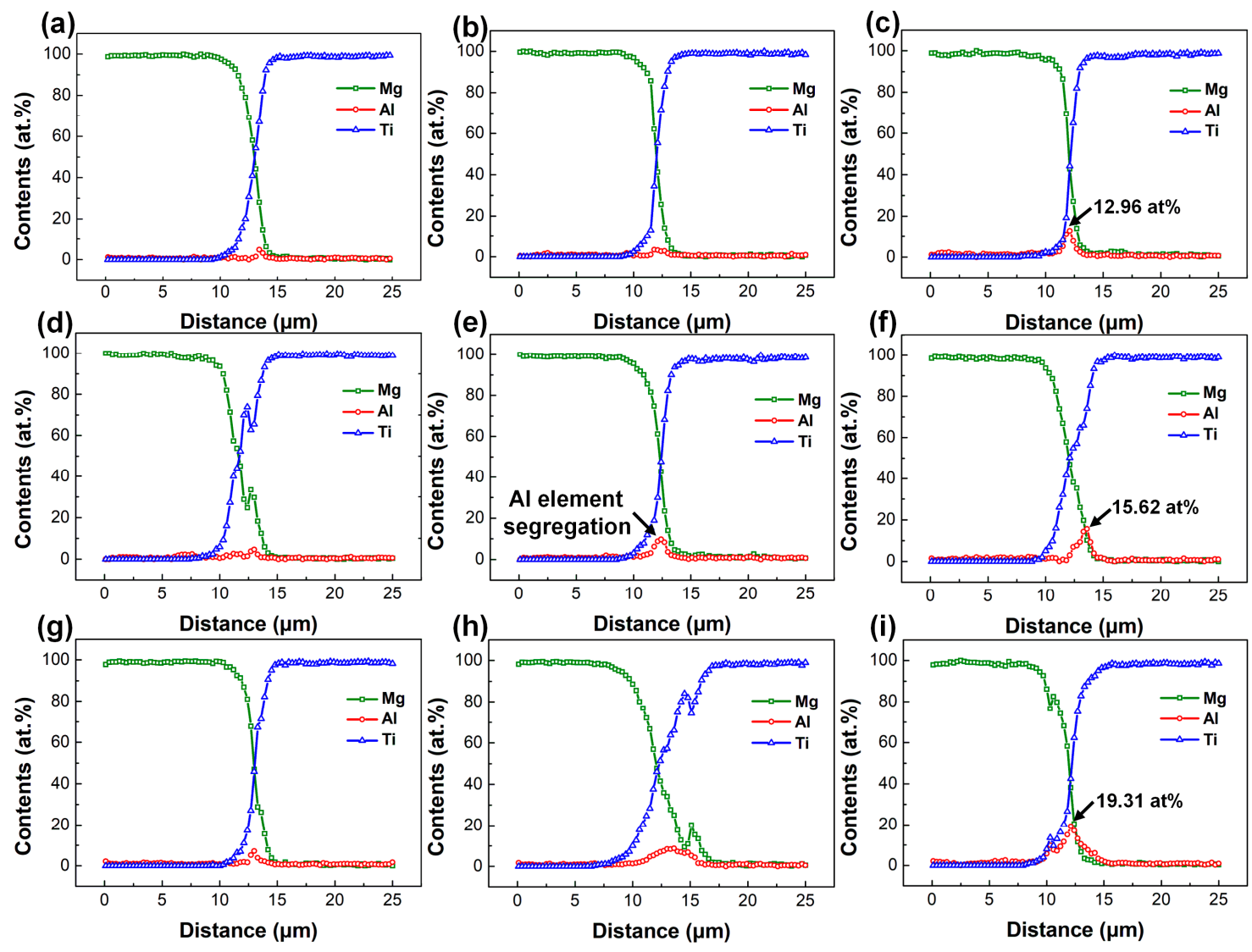

Figure 7. Line scanning results of $\mathrm{Mg} / \mathrm{Ti}$ laser deep penetration welding joints at laser power of $3.5 \mathrm{~kW}$ : (a-c) AZ31/TA2; (d-f) AZ61/TA2; (g-i) AZ91/TA2.

\subsection{Bonding Mechanism}

To clearly clarify the interfacial reaction at Mg-Ti interface, Gibbs free energy and chemical potential of each element (Mg, Al and Ti) at $300 \mathrm{~K}, 900 \mathrm{~K}, 1300 \mathrm{~K}, 1600 \mathrm{~K}$ and $2000 \mathrm{~K}$ were calculated and analyzed. These several temperatures were selected representing different stages, i.e., room temperature; $\mathrm{Mg}, \mathrm{Al}$ and Ti elements remained at a solid state; Ti was at solid state while $\mathrm{Mg}$ and $\mathrm{Al}$ was melted; Ti was at solid state, $\mathrm{Al}$ existed at liquid form while gaseous $\mathrm{Mg}$ appeared; Ti started to be melted. Thermodynamic characteristics at these temperatures could help understand atomic diffusion and interfacial reaction during the cooling process. As shown in Figure 8a, Al element had the lowest chemical potential at $\mathrm{Ti}$ side in $\mathrm{Mg}-\mathrm{Ti}-\mathrm{Al}$ ternary system, indicating that the general diffusion tendency of $\mathrm{Al}$ atoms from $\mathrm{Mg}$ base metal side to $\mathrm{Mg} / \mathrm{Ti}$ interface. The chemical potential gradient of $\mathrm{Al}$ from AZ91, AZ61 and AZ31 to Ti was $-117.65 \mathrm{KJ} / \mathrm{mol},-116.19 \mathrm{KJ} / \mathrm{mol}$ and $-112.49 \mathrm{KJ} / \mathrm{mol}$, respectively, suggesting that the driving force of $\mathrm{Al}$ from $\mathrm{AZ} 91$ to Ti substrate was a little higher than that from the other two base metals. It coincided with the fact that higher content of $\mathrm{Al}$ was detected at the AZ91/Ti interface shown in Figure 7. In addition, $\mathrm{Al}$ atoms could diffuse from $\mathrm{Mg}$ base metal (AZ91, AZ31 or AZ61) to Ti substrate in a wide range. Take AZ91-Ti system as example, Al originally diffused from AZ91 to Ti at Route 1 (shown in Figure 8a), and then continuously diffused to Al-contained Ti base metal at Route 2, Route 3, and even could diffuse to 0.75 at\% Al-contained Ti alloy at Route 11 . However, the maximum Al content at this work was 27.08 at\% (EDS result in Table 4, and as marked in red circle in Figure 8a) due to the high cooling rate of laser welding, which provided a possible formation of $\mathrm{Ti}_{3} \mathrm{Al}$ phase. Ti atoms cannot diffuse to $\mathrm{Mg}$ base metal due to the positive chemical potential difference while they were strongly attracted by the $\mathrm{Al}$ atoms gathered at $\mathrm{Mg} / \mathrm{Ti}$ interface, as shown in Figure 8b, which indicated that the Ti-Al phase was generated at the interface other than in the fusion zone. The Gibbs free energy of $\mathrm{Mg}-\mathrm{Al}-\mathrm{Ti}$ system at different temperature was also 
calculated, based on which possible formation phases could be estimated. Figure $8 \mathrm{c}$ summarizes the $\mathrm{Ti} / \mathrm{Al}$ atom ratio at minimum Gibbs frees energy (the values were shown in Table 5) of $0.001 \mathrm{Mg}-\mathrm{Al}-\mathrm{Ti}$ system (or at Ti base metal) and Figure $8 \mathrm{~d}$ showed the Gibbs free energy at $900 \mathrm{~K}$. At equilibrium state without limit of $\mathrm{Al}$ contents, TiAl phase was estimated to generate as shown in Figure $8 \mathrm{c}$ and Point 1 in Figure $8 \mathrm{~d}$. In this work, maximum $\mathrm{Al}$ content was 27.08 at $\%$ and the phase with $\mathrm{Ti} / \mathrm{Al}$ atom ratio of 2.7 was estimated to form, which turned out to be $\mathrm{Ti}_{3} \mathrm{Al}$ phase (marked as Point 2 in Figure $8 \mathrm{~d}$ ). It also can be estimated in Figure $8 \mathrm{~d}$ that $\mathrm{Mg}_{17} \mathrm{Al}_{12}$ was produced in the fusion zone. The $\mathrm{Mg}-\mathrm{Al}$ eutectic phase with a similar constitution of 0.74 at $\% \mathrm{Mg}$ and $0.25 \mathrm{at} \% \mathrm{Al}$ has been detected in previous work [26].

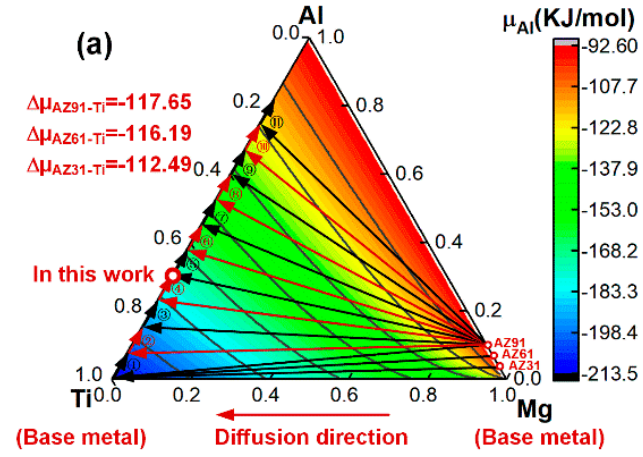

(c)

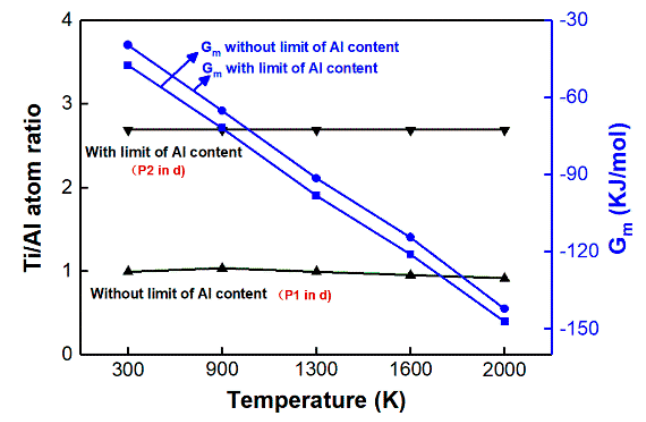

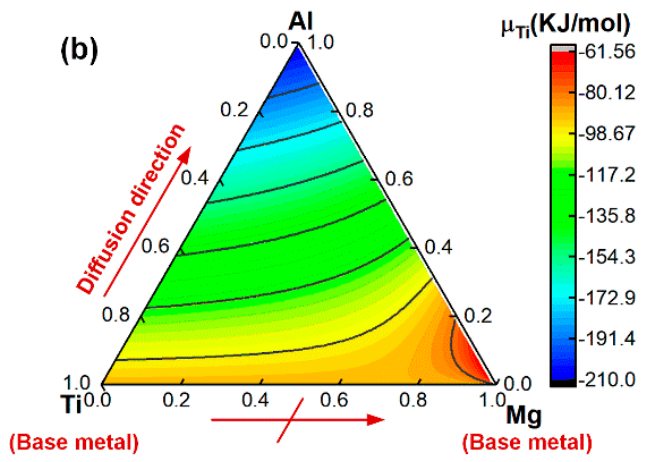

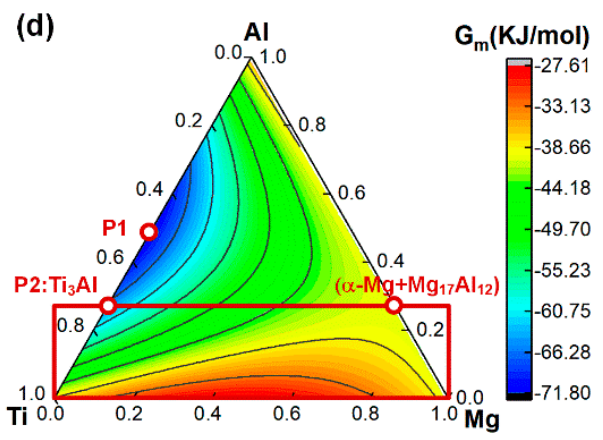

Figure 8. Thermodynamic calculation results: (a,b) chemical potential of $\mathrm{Al}$ and $\mathrm{Ti}$ at $1600 \mathrm{~K}$; (c) Ti/Al atomic ratio at minimum Gibbs free energy of $0.001 \mathrm{Mg}-\mathrm{Al}-\mathrm{Ti}$ system (or at Ti base metal) at different temperatures; (d) Gibbs free energy of Mg-Al-Ti system at $900 \mathrm{~K}$.

Table 5. Minimum Gibbs free energy and corresponding Ti/Al atom ratio in $0.001 \mathrm{Mg}-\mathrm{Al}-\mathrm{Ti}$ systems.

\begin{tabular}{ccccc}
\hline \multirow{2}{*}{ Temperature/K } & \multicolumn{2}{c}{ Without Limit of Al Content } & \multicolumn{2}{c}{ With Lmit of Al Content } \\
\cline { 2 - 5 } & $\begin{array}{c}\text { Minimum Gibbs Free } \\
\text { Energy } \\
\text { (Gm, KJ/mol) }\end{array}$ & $\begin{array}{c}\text { Ti/Al Atom Ratio } \\
\text { at Minimum Gm }\end{array}$ & $\begin{array}{c}\text { Minimum Gibbs Free } \\
\text { Energy } \\
\text { (Gm, KJ/mol) }\end{array}$ & $\begin{array}{c}\text { Ti/Al Atom Ratio } \\
\text { at Minimum Gm }\end{array}$ \\
\hline 300 & -47.43 & 0.994 & -39.57 & 2.69 \\
900 & -71.78 & 1.035 & -65.11 & 2.69 \\
1300 & -98.09 & 0.994 & -91.36 & 2.69 \\
1600 & -121.00 & 0.955 & -114.31 & 2.69 \\
2000 & -147.14 & 0.917 & -142.14 & 2.69 \\
\hline
\end{tabular}

Based on the above analysis, the bonding mechanism of $\mathrm{Mg} / \mathrm{Ti}$ laser deep penetration welding was illuminated and the schematic diagram is shown in Figure 9. Firstly, laser beam irradiated on the $\mathrm{Mg}$ base metal directly. Mg alloys melted under the effect of high temperature. At the same time, laser energy was transferred to the Ti side and the thin TA2 sheets melted simultaneously. The atoms adjacent to the $\mathrm{Mg} / \mathrm{Ti}$ interface were activated. $\mathrm{Mg} / \mathrm{Ti}$ atoms did not interact with each other due to the immiscibility. Hence, the $\mathrm{Mg}$ and Ti atoms hardly diffused to each other in the early stage of the heating. $\mathrm{Al}$ atoms existing in the molten pool at $\mathrm{Mg}$ side started to diffuse to the $\mathrm{Mg} / \mathrm{Ti}$ interface under the driving force with the decrease of chemical potential as shown in Figure 9a. A small amount of 
$\mathrm{Mg}$ atoms would diffuse to $\mathrm{Al}$ atoms due to the attractive effect of $\mathrm{Mg}$ and $\mathrm{Al}$ atoms. As base metal continued to melt, $\mathrm{Al}$ atoms enriched abundantly at the $\mathrm{Mg} / \mathrm{Ti}$ interface. $\mathrm{Ti}$ atoms existing in the molten pool at $\mathrm{Ti}$ side started to diffuse to $\mathrm{Mg} / \mathrm{Ti}$ interface under the attraction of the $\mathrm{Al}$-enriched layer and the stirring effect of molten pool. At the same time, the increase of Ti fraction in the molten pool resulting from the continuous dissolution of TA2 would further accelerate the diffusion of Al atoms as shown in Figure 9b. As the temperature decreased, the increased amount of $\mathrm{Al}$ and Ti atoms at the front of the $\mathrm{Mg} / \mathrm{Ti}$ interface provided convenient conditions to generate the $\mathrm{Al} / \mathrm{Ti}$ intermetallic compound layer [27] as shown in Figure 9c. As the temperature further decreased, eutectic reaction occurred and structure consisted of $\alpha-\mathrm{Mg}$ and $\mathrm{Mg}_{17} \mathrm{Al}_{12}$ compound formed at the fusion zone of $\mathrm{Mg}$. In addition, with the condition of laser deep penetration welding, part of Ti atoms entered the fusion zone of $\mathrm{Mg}$ alloys with the stirring effect of the keyhole. These $\mathrm{Ti}$ atoms mixed with $\mathrm{Mg}$ and $\mathrm{Mg}-\mathrm{Al}$ phase leading to the formation of the brittle phase in the fusion zone [21].
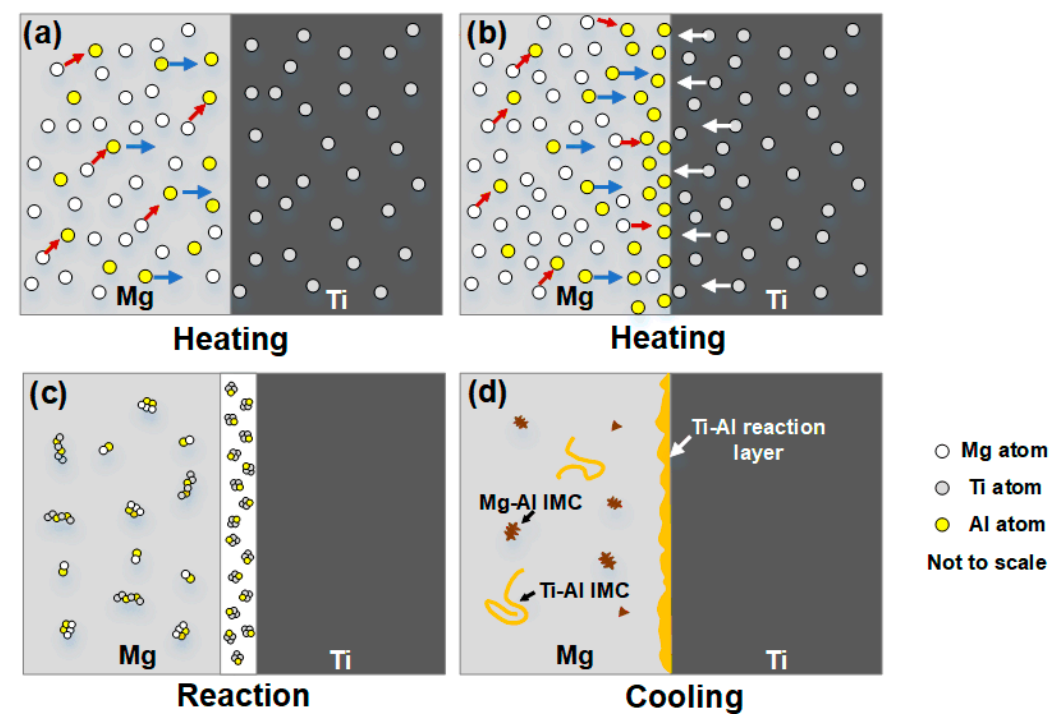

Figure 9. Reaction mechanism of laser deep penetration of $\mathrm{Mg} / \mathrm{Ti}$ dissimilar joints: $(\mathbf{a}, \mathbf{b})$ process of welding heating; (c) process of atomic diffusion reaction; (d) process of cooling and compound formation.

According to the above results, it was found that the interface reaction of $\mathrm{Mg} / \mathrm{Ti}$ laser welding was related to the amount of activated $\mathrm{Al}$ atoms diffusing from $\mathrm{Mg}$ base metal to the interface of $\mathrm{Mg} / \mathrm{Ti}$, which was influenced by $\mathrm{Al}$ content of the $\mathrm{Mg}$ alloy base metal and specific welding process with various thermal cycles at the different interface positions. According to the results of line scanning, the segregation of $\mathrm{Al}$ at the upper interface was extremely weak, while the enrichment degree of $\mathrm{Al}$ atoms in the lower position was much higher than that in the upper or middle position in the same joints. This phenomenon was related to the stirring action of molten pool induced by keyhole during laser deep penetration welding process and the stirring effect of molten pool is shown in Figure 10. The stirring effect on the molten pool became stronger when approaching the keyhole. Therefore, the large size of the keyhole in the upper part of the joint prevented the full contact between the liquid $\mathrm{Mg}$ and $\mathrm{Ti}$, which made it difficult for $\mathrm{Al}$ element in base metal to diffuse to the interface and produce an obvious reaction layer. The keyhole effect decreased along the plate thickness. With the depth of the keyhole increased, the penetration ability of the keyhole was weakened, which reduced the stirring effect of molten pool and provided more favorable conditions for the diffusion of the $\mathrm{Al}$ element. As a result, the Al element could fully diffuse to the interface resulting in a higher fraction of $\mathrm{Al}$ elements at the $\mathrm{Mg} / \mathrm{Ti}$ interface in the lower part of the joints. Comparing joints using AZ31, AZ61 and AZ91 as the Mg base metal, it was found that with the increase of Al content in Mg alloy base metal, the interface reaction layer became more evident, especially in the middle and lower parts of the joints. This observation was in consistence with the results obtained in friction stir welding 
of $\mathrm{Mg} / \mathrm{Ti}$ [21]. In this previous study, the increased $\mathrm{Al}$ content in $\mathrm{Mg}$ alloy base metal led to more activated $\mathrm{Al}$ atoms, which promote sound metallurgical reaction between $\mathrm{Mg}$ and Ti base metal.

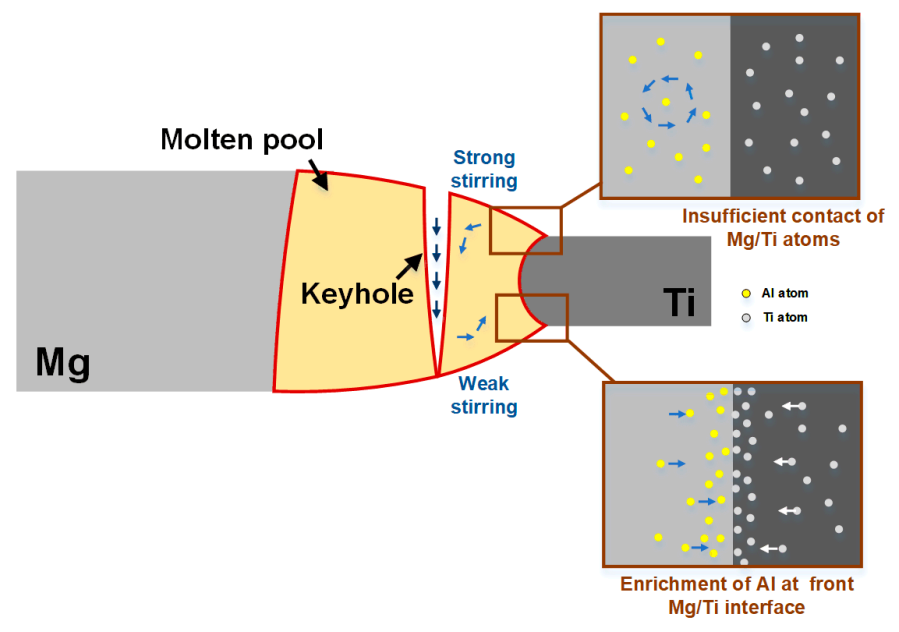

Figure 10. Schematic diagram of stirring effect of molten pool.

\subsection{Fracture Behaviors}

In order to analyze the effect of three types of $\mathrm{Mg}$ base metal with different $\mathrm{Al}$ content on the mechanical properties of the weld, the load-displacement curve and fracture location at laser power of $3.5 \mathrm{~kW}$ was shown in Figure 11. It was found that the failure position of AZ31/TA2 and AZ91/TA2 joint was at weld seam. AZ31/TA2 joints failed without deformation significantly while certain necking on the Ti side was obtained during the fracture process of AZ91/TA2. AZ61/TA2 joints fractured at the Ti base metal, indicating good interfacial bonding occurred at the interface. The displacement generated during the tensile process of AZ61/TA2 joint was much greater than that of AZ31/TA2 and AZ91/TA2.

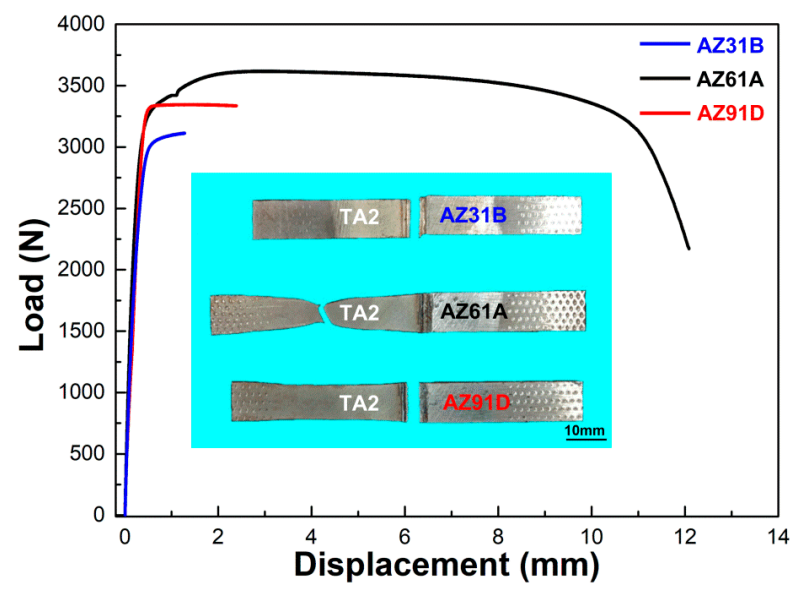

Figure 11. Load-displacement curves and fracture mode of laser deep penetration welding of $\mathrm{Mg} / \mathrm{Ti}$ at lase power of $3.5 \mathrm{~kW}$.

Figure 12 shows the fracture behavior of AZ31/TA2 and AZ91/TA2 joints with the laser power of $3.5 \mathrm{~kW}$. It can be seen from Figure 12a,b that fracture surface of AZ31/TA2 joints along the weld direction had two different areas: zone 1 and zone 3 characterized by a rough surface where a small amount of $\mathrm{Mg}$ in middle part of joints was observed. The fracture surface of zone 2 and zone 4 was smooth, where the cracks propagated rapidly along the $\mathrm{Mg} / \mathrm{Ti}$ interface. The cross-sectional morphology showed that the joints failed entirely along the $\mathrm{Mg} / \mathrm{Ti}$ interface. Compared with the AZ31/TA2 joint, the AZ91/TA2 joint did not completely fracture along the $\mathrm{Mg} / \mathrm{Ti}$ interface. The residual $\mathrm{Mg}$ alloy was observed 
attached to the Ti surface in the middle region of the joint as shown in Figure 12e, which indicated that the crack propagated inside the $\mathrm{Mg}$ alloy at the middle part of joints instead of fracturing along the $\mathrm{Mg} / \mathrm{Ti}$ interface during the tensile process. The fracture surface of AZ91/TA2 joints along the weld direction showed uniform morphology along the weld direction, suggesting that joints failed along the $\mathrm{Mg} / \mathrm{Ti}$ interface at upper and bottom area while inside of the $\mathrm{Mg}$ alloy in the middle region. Combining the microstructure shown in Figure 6, when AZ31 was employed as base metal, a reliable intermetallic compound layer cannot be formed at the interface due to the low Al content, resulting in a low $\mathrm{Mg} / \mathrm{Ti}$ interface strength. Therefore, cracks propagated and eventually failed along the interface in AZ31/TA2 joint. When AZ91 was used as base metal, the Ti-Al reaction layer was found at the interface, which improved the strength of the $\mathrm{Mg} / \mathrm{Ti}$ interface compared with the AZ31/TA2 joints. In addition, Figure 12e revealed that linear $\mathrm{Ti}-\mathrm{Al}$ structure existed in the fusion zone of $\mathrm{Mg}$. A similar phenomenon was observed in previous research [25]. In heating and cooling process of laser welding, some Ti fragments were involved into the fusion zone and interacted with the Al element that precipitated from $\mathrm{Mg}(\mathrm{Al})$ solid solution, giving rise to the formation of the $\mathrm{Ti}-\mathrm{Al}$ brittle phase and reducing the tensile property of the $\mathrm{Mg}$ fusion zone.

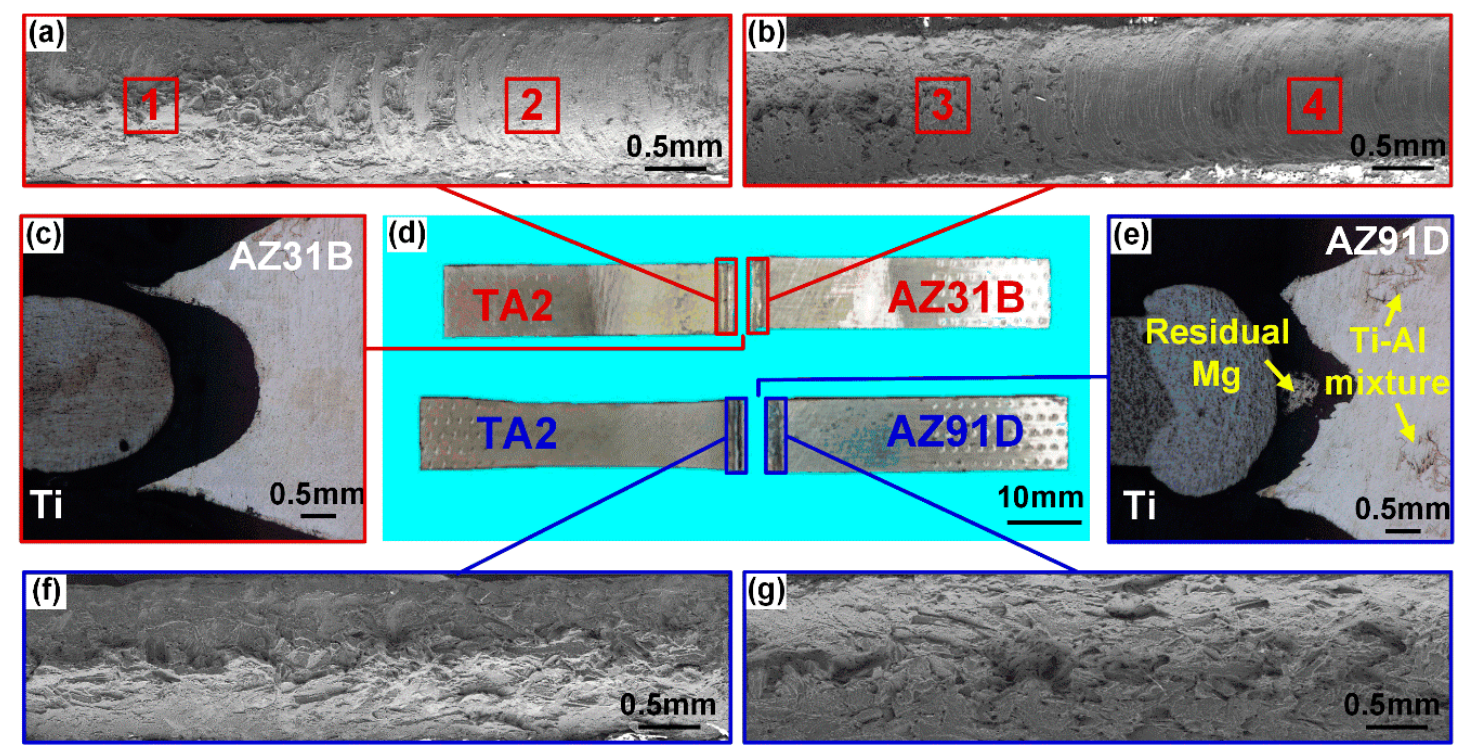

Figure 12. Fractography of $\mathrm{Mg} / \mathrm{Ti}$ joints: $(\mathbf{a}, \mathbf{b})$ scanning electron microscope (SEM) images of fracture surface of TA2/AZ31B joints; (c) fracture path of TA2/AZ31B joints; (d) macro-morphology of TA2/AZ31B and TA2/AZ91D joints; (e) fracture path of TA2/AZ91D joints; (f,g) SEM images of fracture surface of TA2/AZ91D joints.

Figure 13 showed the SEM morphology of fracture surface of the AZ31/TA2 joint. Figure 13a,b presented areas 1 and 2 in Figure 11 at the Ti side, respectively. The feature of fracture surface at Ti side was characterized by cleavage steps and river-like patterns indicating the brittle fracture. At the Ti side, the fracture surface consisted of mixed structure of $\mathrm{Ti}-\mathrm{Al}$ phase $(26.88 \mathrm{at} \% \mathrm{Al}, 67.72 \mathrm{at} \% \mathrm{Ti})$ and residual $\mathrm{Mg}(96.17 \%$ at $\% \mathrm{Mg}, 3.71 \mathrm{at} \% \mathrm{Al}, 0.12$ at $\% \mathrm{Ti})$. Tan et al. [19] obtained similar results in that the serrate-shaped microstructure reaction layer was attached to the Ti substrate, which mainly resulted in the high resistance to crack propagation. Figure $13 \mathrm{~b}$ shows the smooth and flat area where the crack quickly propagated. The fracture surface on the Ti side was mainly identified as the Ti-Al compound (12.02 at\% Al, 81.13 at $\%$ Ti) with few residual strips of magnesium alloy $(92.43 \%$ at $\% \mathrm{Mg}$, $5.44 \mathrm{at} \% \mathrm{Al}, 2.13 \mathrm{at} \% \mathrm{Ti})$. The formation of the Ti-Al phase at the fracture surface confirmed that $\mathrm{Al}$ element had diffused to $\mathrm{Mg} / \mathrm{Ti}$ interface. However, insufficient reaction of $\mathrm{Mg} / \mathrm{Ti}$ due to the low $\mathrm{Al}$ content resulted in lower tensile load and joint toughness. Figure 13c,d show the fracture surface morphology on the $\mathrm{Mg}$ side of AZ31/TA2 joint, which mainly consisted of $\mathrm{Mg}$ alloy $(97.29 \%$ at $\% \mathrm{Mg}$, $2.57 \mathrm{at} \% \mathrm{Al}, 0.15 \mathrm{at} \% \mathrm{Ti})$. However, the $\mathrm{Al}$ content at the area where the cracks propagated quickly in 
Figure 13d exceeded that in the $\mathrm{Mg}$ base metal (10.82 at $\% \mathrm{Al}, 89.09 \mathrm{at} \% \mathrm{Mg})$, indicating that part of the $\mathrm{Al}$ atoms still concentrated in the $\mathrm{Mg}$ alloy and did not participate in the interface reaction. The interface reaction was insufficient due to its low $\mathrm{Al}$ content at $\mathrm{Mg} / \mathrm{Ti}$ interface, which resulted in the poor mechanical property of AZ31/TA2 joints.

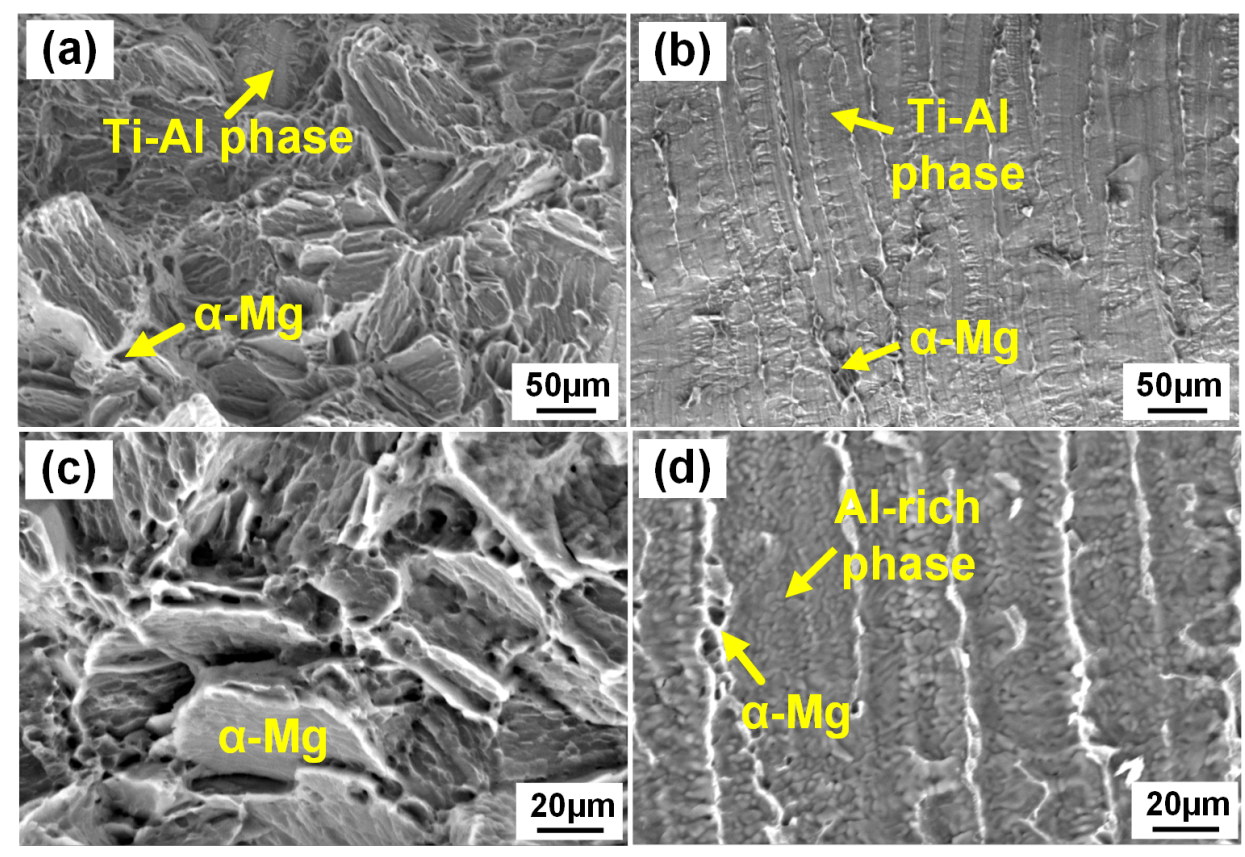

Figure 13. SEM morphology of fracture surface of AZ31/TA2 joints: (a) area 1 in Figure 9 at the Ti side; (b) area 2 in Figure 9 at the Ti side; (c) area 3 in Figure 9 at the Mg side; (d) area 4 in Figure 9 at the Mg side.

Figure 14 shows SEM morphology of the AZ91/TA2 joint fracture on Ti side at the middle regions. In this region, the fracture surface completely consisted of $\mathrm{Mg}(94.02 \%$ at $\% \mathrm{Mg}, 5.15$ at $\% \mathrm{Al}, 0.82$ at $\% \mathrm{Ti})$ indicating that the joints failed inside the $\mathrm{Mg}$ alloy. Higher magnification exhibited typical morphology of mixed of cleavage fracture and ductile fracture. Nevertheless, little Ti-Al phase $(19.26 \mathrm{at} \% \mathrm{Al}$, $74.37 \mathrm{at} \% \mathrm{Ti}$ ) was observed inside the $\mathrm{Mg}$ alloy which corresponded to Figure 12. The formation of brittle phases in the fusion zone of $\mathrm{Mg}$ alloy resulted in the weakest area of the joint transferring from the $\mathrm{Mg} / \mathrm{Ti}$ interface to the fusion zone of $\mathrm{Mg}$.

The main reason for the differences of the property was the diffusion and reaction behavior of the $\mathrm{Al}$ element during the welding process. As the $\mathrm{Al}$ content in $\mathrm{Mg}$ base metal increased, more $\mathrm{Al}$ atoms diffused to the interface and participated in the interfacial reaction, which was beneficial to the formation of a reliable reaction layer at the interface. Therefore, the interfacial bonding degree of the AZ31/TA2 joint was the weakest, resulting in quick propagation of a crack along the interface during the tensile process. However, the increasing quantity of Al content in AZ91 Mg alloys led to the formation of brittle phases such as $\mathrm{Mg}-\mathrm{Al}$, $\mathrm{Ti}-\mathrm{Al}$ phases in the fusion zone of $\mathrm{Mg}$, which increased the crack propagation and damaged the joint performance. The interfacial strength was enhanced while the property of the fusion zone was damaged for AZ91/TA2 joints, which was responsible for the transformation of the weakest position from the $\mathrm{Mg} / \mathrm{Ti}$ interface to the fusion zone of $\mathrm{Mg}$ alloys at the middle region of joints. When AZ61 was employed as the base metal, the appropriate Al content not only ensured a reliable reaction layer at the $\mathrm{Mg} / \mathrm{Ti}$ interface which improved the interfacial strength, but also did not seriously damage the performance of the fusion zone of the $\mathrm{Mg}$ alloy. Therefore, AZ61/TA2 joints had good performance as expected. 

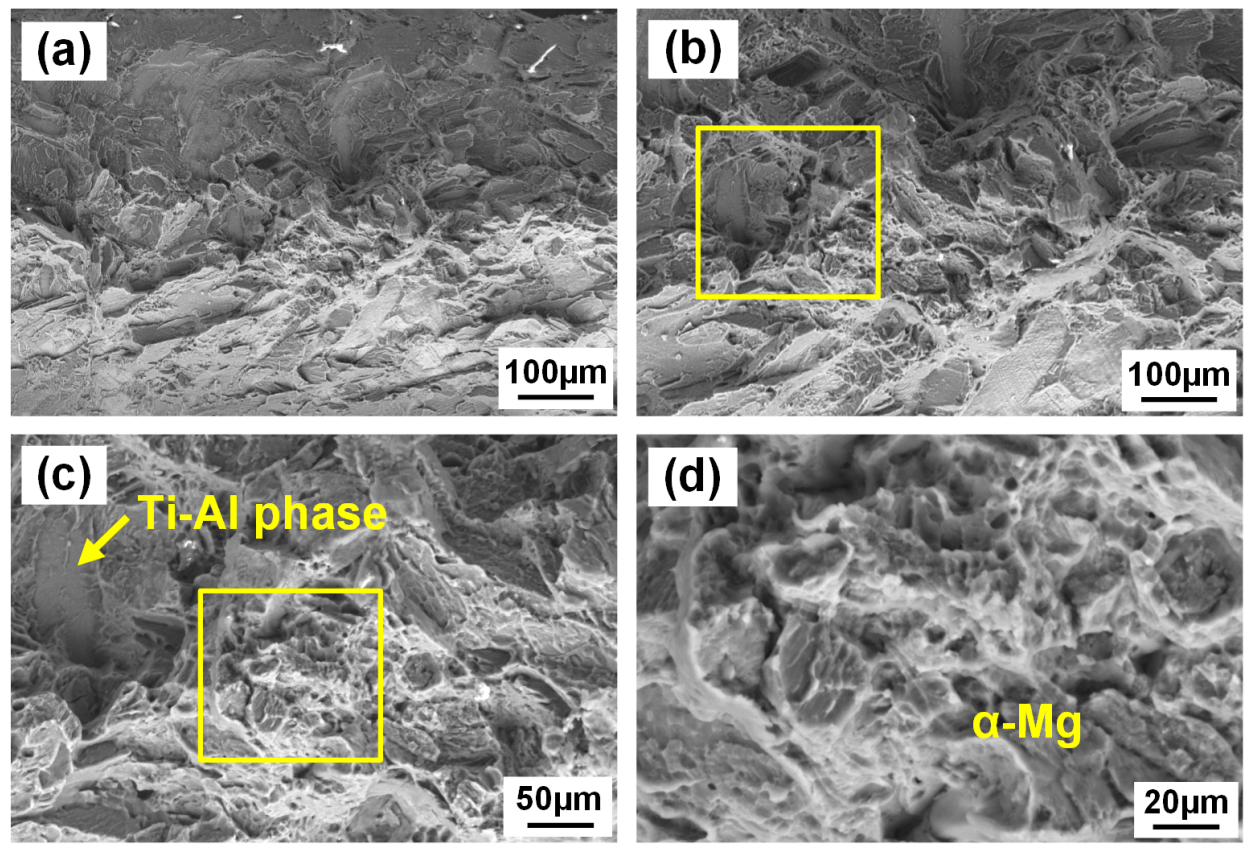

Figure 14. SEM morphology of fracture surface of AZ91/TA2 at the Ti side: $(\mathbf{a}, \mathbf{b})$ middle area in fracture surface; (c) higher magnification of zone b; (d) higher magnification of zone c.

\section{Conclusions}

Laser deep penetration of $\mathrm{Mg}$ alloys with different $\mathrm{Al}$ content (AZ31B, AZ61A, AZ91D) and TA2 with unequal thickness was performed. The effect of Al content on weld appearances, cross-sectional morphology, microstructure of $\mathrm{Mg} / \mathrm{Ti}$ interface and mechanical property was observed and analyzed. The following conclusions were drawn:

1. With the increase of laser power, the front side of the weld seam gradually collapsed and the bead width on the back side increased. The change of the $\mathrm{Mg}$ base metal did not affect the joint appearance. The strength of three types of joints reached highest with laser power of $3.5 \mathrm{~kW}$.

2. An obvious segregation of $\mathrm{Al}$ elements was obtained. The enrichment degree of $\mathrm{Al}$ was promoted when $\mathrm{Al}$ content in the $\mathrm{Mg}$ base metal increased. The $\mathrm{Al}$ fraction reached $19.31 \mathrm{at} \%$ when AZ91 was employed. A reaction layer was obtained along the $\mathrm{Mg} / \mathrm{Ti}$ interface indicating that metallurgical bonding of $\mathrm{Mg} / \mathrm{Ti}$ was achieved and the degree of interfacial reaction improved with increasing $\mathrm{Al}$ content in the $\mathrm{Mg}$ base metal.

3. The maximum fracture load reached $3597 \mathrm{~N}$ when $\mathrm{AZ} 61$ was used as the Mg base metal. Both the sound mechanical property of AZ61/Ti interface and fusion zone resulted in the failure at the $\mathrm{Ti}$ base metal.

4. AZ31/TA2 joints failed along the $\mathrm{Mg} / \mathrm{Ti}$ interface where the cracks rapidly propagated due to the poor interfacial bonding. AZ91/TA2 joints failed in the Mg fusion zone in the middle area which resulted from the improvement of interfacial strength and declining strength of the fusion zone.

Author Contributions: Conceptualization, W.D. and H.Z.; methodology, C.T.; validation, C.T., B.C. and H.Z; formal analysis, C.T.; investigation, R.H. and X.G.; resources, C.T. and H.Z; data curation, R.H.; writing-original draft preparation, R.H.; writing - review and editing, C.T.; supervision, C.T. and H.Z.; project administration, C.T. and H.Z; funding acquisition, C.T. All authors have read and agreed to the published version of the manuscript.

Funding: This research was funded by National Natural Science Foundation of China (Grant No.51875129), Key Research \& Development Program in Shandong Province (Grant No. 2017GGX30147 and 2017CXGC0811).

Acknowledgments: The authors would like to show sincere gratitude to: Caiwang Tan and Hongyun Zhao, two respectable and responsible scholars, which provided valuable guidance in this work.

Conflicts of Interest: The authors declare no conflict of interest. 


\section{References}

1. Chen, X.; Lei, Z.; Chen, Y.; Han, Y.; Jiang, M.; Tian, Z.; Bi, J.; Lin, S.; Jiang, N. Effect of laser beam oscillation on laser welding-brazing of Ti/Al dissimilar metals. Materials 2019, 12. [CrossRef] [PubMed]

2. Sherif, E.M.; AlHazaa, A.N.; Abdo, H.S. Manufacturing of Mg-Ti couples at different heat treatment temperatures and their corrosion behavior in chloride solutions. Materials 2019, 12. [CrossRef]

3. Xu, C.; Peng, C. Mechanical properties and microstructure analysis of welding-brazing of $\mathrm{Al} / \mathrm{Ti}$ butt joint with $\mathrm{Zn}$ foil additive. Mater. Res. Express 2020, 7, 026542. [CrossRef]

4. Xia, H.; Tao, W.; Li, L.; Tan, C.; Zhang, K.; Ma, N. Effect of laser beam models on laser welding-brazing Al to steel. Opt. Laser Technol. 2020, 122, 105845. [CrossRef]

5. Zhao, Y.; Luo, Y.; Zhang, Z.; Zhang, H.; Guo, X.; Wang, S.; Cui, H.; Zhang, Y. Fractal dimension characterization of joint surface morphology on dissimilar friction stir lap welding of Al/Mg. Materials 2019, 12. [CrossRef] [PubMed]

6. Xu, Y.; Ke, L.; Mao, Y.; Liu, Q.; Xie, J.; Zeng, H. Formation investigation of intermetallic compounds of thick plate $\mathrm{Al} / \mathrm{Mg}$ alloys joint by friction stir welding. Materials 2019, 12. [CrossRef]

7. $\mathrm{Xu}, \mathrm{C}$. The influence of $\mathrm{Al}$ content from filler metals on tungsten inert gas welding-brazing of $\mathrm{Mg}$-Ti. Mater. Res. Express 2019, 6, 116567. [CrossRef]

8. Li, J.; Liu, Y.; Zhen, Z.; Jin, P.; Sun, Q.; Feng, J. Weld formation mechanism and microstructural evolution of TC4/304 stainless steel joint with Cu-based filler wire and preheating. Materials 2019, 12, 3071. [CrossRef]

9. Guo, N.; Cheng, Q.; Zhang, X.; Fu, Y.; Huang, L. Microstructure and mechanical properties of underwater laser welding of titanium alloy. Materials 2019, 12. [CrossRef]

10. Auwal, S.T.; Ramesh, S.; Zhang, Z.; Yusof, F.; Liu, J.; Tan, C.; Manladan, S.M.; Tarlochan, F. Effect of copper-nickel interlayer thickness on laser welding-brazing of Mg/Ti alloy. Opt. Laser Technol. 2019, 115, 149-159. [CrossRef]

11. Auwal, S.T.; Ramesh, S.; Zhang, Z.; Liu, J.; Tan, C.; Manladan, S.M.; Yusof, F.; Tarlochan, F. Influence of electrodeposited $\mathrm{Cu}-\mathrm{Ni}$ layer on interfacial reaction and mechanical properties of laser welded-brazed $\mathrm{Mg} / \mathrm{Ti}$ lap joints. J. Manuf. Process. 2019, 37, 251-265. [CrossRef]

12. Zhang, Z.; Tan, C.; Zhao, X.; Chen, B.; Song, X.; Zhao, H. Influence of Cu coating thickness on interfacial reactions in laser welding-brazing of Mg to Ti. J. Mater. Process. Technol. 2018, 261, 61-73. [CrossRef]

13. Tan, C.; Yang, J.; Zhao, X.; Zhang, K.; Song, X.; Chen, B.; Li, L.; Feng, J. Influence of Ni coating on interfacial reactions and mechanical properties in laser welding-brazing of $\mathrm{Mg} / \mathrm{Ti}$ butt joint. J. Alloys Compd. 2019, 764, 186-201. [CrossRef]

14. Tan, C.; Zang, C.; Zhao, X.; Xia, H.; Lu, Q.; Song, X.; Chen, B.; Wang, G. Influence of Ni-coating thickness on laser lap welding-brazing of Mg/Ti. Opt. Laser Technol. 2018, 108, 378-391. [CrossRef]

15. Liu, J.; T, C.; Wu, L.; Zhao, X.; Zhang, Z.; Chen, B.; Song, X.; Feng, J. Butt laser welding-brazing of AZ31Mg alloy to Cu coated Ti-6Al-4V with AZ92 Mg based filler. Opt. Laser Technol. 2019, 117, 200-214. [CrossRef]

16. Cao, R.; Wang, T.; Wang, C.; Feng, Z.; Lin, Q.; Chen, J.H. Cold metal transfer welding-brazing of pure titanium TA2 to magnesium alloy AZ31B. J. Alloys Compd. 2014, 605, 12-20. [CrossRef]

17. Hu, X.; Mei, Z.; Li, L.; Zhou, X.; Dong, S. Interface microstructure in laser welding-brazing of AZ31B/TC4 dissimilar alloys. Adv. Mater. Res. 2014, 875-877, 1503-1506. [CrossRef]

18. Tan, C.; Song, X.; Chen, B.; Li, L.; Feng, J. Enhanced interfacial reaction and mechanical properties of laser welded-brazed Mg/Ti joints with Al element from filler. Mater. Lett. 2016, 167, 38-42. [CrossRef]

19. Tan, C.; Chen, B.; Meng, S.; Zhang, K.; Song, X.; Zhou, L.; Feng, J. Microstructure and mechanical properties of laser welded-brazed Mg/Ti joints with AZ91 Mg based filler. Mater. Des. 2016, 99, 127-134. [CrossRef]

20. Zang, C.; Liu, J.; Tan, C.; Zhang, K.; Song, X.; Chen, B.; Li, L.; Feng, J. Laser conduction welding characteristics of dissimilar metals Mg/Ti with $\mathrm{Al}$ interlayer. J. Manuf. Process. 2018, 32, 595-605. [CrossRef]

21. Aonuma, M.; Nakata, K. Effect of alloying elements on interface microstructure of Mg-Al-Zn magnesium alloys and titanium joint by friction stir welding. Mater. Sci. Eng. B 2009, 161, 46-49. [CrossRef]

22. GB/T 2650-2008/ISO 6-9016: 2001. Tensile Test Method on Welded Joints; Standardization Administration of the People's Republic of China: Harbin, China, 2008.

23. Toop, G. Predicting ternary activities using binary data. Trans. Am. Inst. Min. Eng. 1965, 233, 850-855.

24. Miedema, A.; de Chatel, P.; de Boer, F. Cohesion in alloys-Fundamentals of a semi-empirical model. Physica B 1980, 100, 1-28. [CrossRef] 
25. Gao, M.; Wang, Z.M.; Li, X.Y.; Zeng, X.Y. Laser keyhole welding of dissimilar Ti-6Al-4V titanium alloy to AZ31B magnesium alloy. Metall. Mater. Trans. A 2011, 43, 163-172. [CrossRef]

26. Zhao, X.; Tan, C.; Xiao, L.; Xia, H.; Chen, B.; Song, X.; Li, L.; Feng, J. Effect of the Ni coating thickness on laser welding-brazing of Mg/steel. J. Alloys Compd. 2018, 769, 1042-1058. [CrossRef]

27. Gao, M.; Mei, S.; Li, X.; Zeng, X. Characterization and formation mechanism of laser-welded Mg and Al alloys using Ti interlayer. Scr. Mater. 2012, 67, 193-196. [CrossRef]

(c)

(C) 2020 by the authors. Licensee MDPI, Basel, Switzerland. This article is an open access article distributed under the terms and conditions of the Creative Commons Attribution (CC BY) license (http://creativecommons.org/licenses/by/4.0/). 